\title{
WestVirginiaUniversity
}

THE RESEARCH REPOSITORY @ WVU

West Virginia Agricultural and Forestry Experiment

Davis College of Agriculture, Natural Resources

Station Bulletins

And Design

$1-1-1952$

\section{A leaf analyses survey of apple orchards in West Virginia}

Arthur H. Thompson

R.S. Marsh

Oscar E. Schubert

Follow this and additional works at: https://researchrepository.wvu.edu/ wv_agricultural_and_forestry_experiment_station_bulletins

\section{Digital Commons Citation}

Thompson, Arthur H.; Marsh, R. S.; and Schubert, Oscar E., "A leaf analyses survey of apple orchards in West Virginia" (1952). West Virginia Agricultural and Forestry Experiment Station Bulletins. 356.

https://researchrepository.wvu.edu/wv_agricultural_and_forestry_experiment_station_bulletins/355 @ WVU. It has been accepted for inclusion in West Virginia Agricultural and Forestry Experiment Station Bulletins by an authorized administrator of The Research Repository@WVU. For more information, please contact ian.harmon@mail.wvu.edu. 


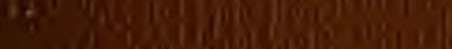

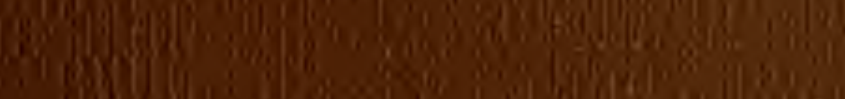
S.

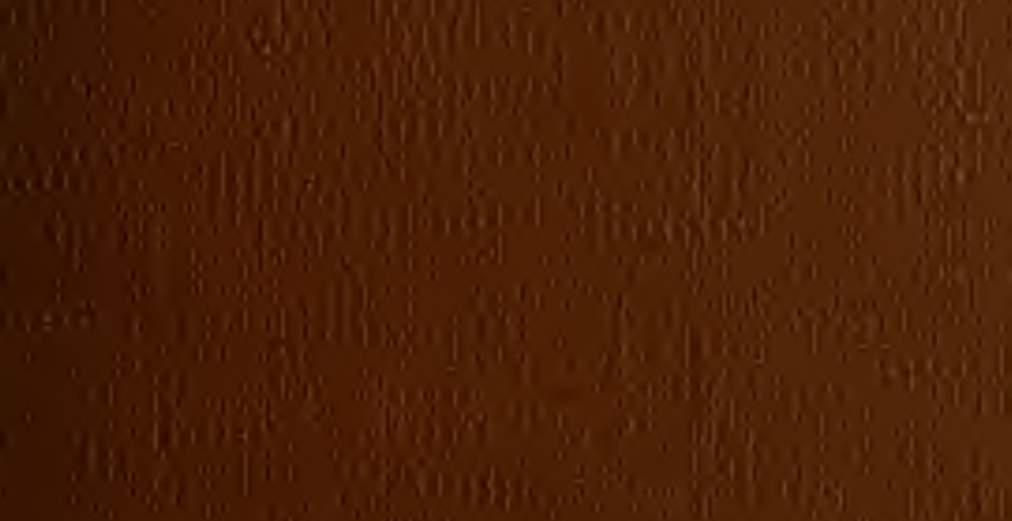
I

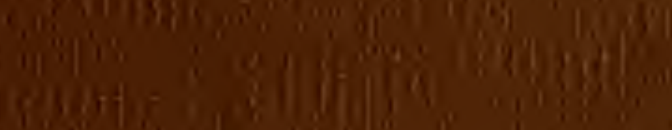
(1) (3), in? (2) 3. 3) (2. 6.6.

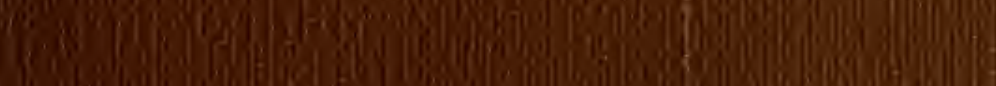

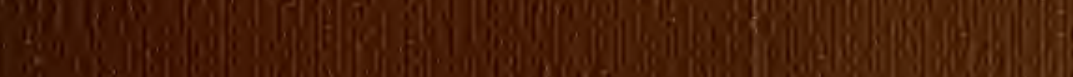

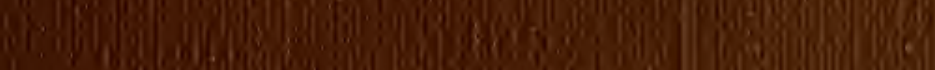


Digitized by the Internet Archive in 2010 with funding from

Lyrasis Members and Sloan Foundation 


\section{SUMMARY}

A leaf analyses survey was made in 1950 as the first part of a general apple nutrition project undertaken by the West Virginia University Agricultural Experiment Station. Nitrogen, phosphorus, potassium, calcium, and magnesium determinations were made on 209 leaf samples collected from orchards growing in limestone, shale, and chert soils. In a few orchards the levels of nitrogen, potassium, and magnesium in the leaves were below the generally accepted critical levels; however, no serious deficiencies existed. The survey supports the continued recommendation of nitrogen only as a fertilizer for apple orchards in West Virginia.

West Virginio University

Agricultural Experiment Station

College of Agriculture, Forestry, and Home Economics

H. R. Varney, Director

Morgantown, West Virginia 


\title{
A LEAF ANALYSES SURVEY OF APPLE ORCHARDS IN WEST VIRGINIA
}

\author{
A. H. Thompson, R. S. Marsh, and O. E. Schubert
}

\section{Introduction}

Since the need for annual applications of nitrogen to apple trees in est Virginia was first demonstrated in 1920 (1), the use of nitrogen ertilizers has been a standard commercial practice throughout the tate. There has been much variation, however, in the attention given is matter by apple growers. Many growers have applied adequate mounts of nitrogen to insure maximum growth and yield. Others have ot maintained necessary levels of nitrogen in their apple orchards, nd yields of fruit have been smaller. Although most apple growers $f$ the State recognize the need for nitrogen, the majority have used nly the minimum amount necessary for satisfactory yields.

The West Virginia University Agricultural Experiment Station has ecommended use of nitrogen ferrilizers in apple orchards for about hirty years. During this period some work has been done with other lements known to be necessary for plant growth. So far no evidence as been obtained to show a need for any element other than nitrogen n the orchard fertilizer application, with the exception of boron in a ew scattered orchards.

Recent work $(4,5,9,11,12)$ has indicated that deficiencies of poassium and magnesium are present in orchards from New England own the Atlantic seaboard to Maryland. Although most of these deiciencies have been encountered in peach orchards that have been ultivated for many years, several instances of low potassium and low ragnesium have been found in apple orchards. These discoveries ave been made by means of chemical analyses of leaves taken from he various orchards studied. Leaf analysis as a method for the diagosis of mineral deficiencies is becoming widely used in the United tates. By itself it often is not conclusive evidence of the tree's utritional status. Leaf analysis, however, offers a possibility of obaining first-hand information on the approximate nutrient status if fruit trees. In this way it is not necessary to resort to expensive nd time-consuming orchard fertilizer experiments. Such experiments isually are impossible on a State-wide basis. 
Leaf analyses are now widely regarded as essential forerunner of any fertilizer experiment on apple trees. Frequently in the pas negative results have been obrained from sound fertilizer experiments Leaf analyses would have eliminated many blocks of trees from con sideration as a site for some of these experiments simply because thi element or elements in question were already present in the trees i sufficient amounts.

- Leaf analyses, then, for experimental purposes afford an inex pensive and rapid means of determining the mineral nutrient status of : given orchard. This method also makes it possible to survey rathe quickly many apple orchards in a given area for the purpose of de termining if deficiencies exist as well as the extent to which sucl deficiencies occur.

\section{THE SURVEY}

An apple nutrition project was started in 1950 at the West Virgini: University Agricultural Experiment Station since deficiencies of po tassium and magnesium are known to exist in near-by areas. Also certain information concerning the nutritional status of apple tree: would be invaluable in the event deficiencies were found. A surve: was planned to determine the nutrient status of West Virginia appl orchards as measured by leaf analyses. For this purpose, sample: of leaves were collected from seventy-one orchards in the State be tween July 11 and August 11, 1950. Five median leaves on curren season's growth were taken from each of three trees for a sample. Th leaves were oven dried and ground in a Wiley mill. With the exception of the University orchard at Morgantown, the orchards sampled wern located in Hampshire, Morgan, Berkeley, and Jefferson counties. The varieties sampled included York, Stayman, Delicious, Rome, Grimes and Golden Delicious. The 209 samples collected were analyzed it the laboratory of the University Experinent Farm at Kearneysville is the winter of 1950-51. Analyses were made according to methods out lined by Lindner (10). Determinations were made to include the nitro gen, phosphorus, potassium, calcium, and magnesium content of eacl sample.

The apple orchards in the Eastern Panhandle of West Virginia ar growing on three general soil classes: limestone, shale, and chert When the leaf analyses were summarized according to these three soi classes, certain interesting trends were noted. As can be seen it Table 1, it was found that the nitrogen content of leaves was lowes in trees growing in limestone solls. 
able 1. Leaf analyses of apple orchards summarized according to soil classes.

\begin{tabular}{lcc|ccc|c|c}
\hline & No. of & \multicolumn{5}{|c}{ Mineral content as per cent of dry weight } \\
\cline { 3 - 7 } iail Class & Samples & nitrogen & phosphorus & potassium & calcium & magnesium \\
\hline imestone & 115 & 1.93 & .198 & 1.83 & 1.32 & .294 \\
ihale & 72 & 2.11 & .190 & 1.68 & 1.17 & .302 \\
ihert & 17 & 2.12 & .198 & 1.53 & 1.19 & .268 \\
LSD* & & .102 & & .118 & .120 & \\
\hline
\end{tabular}

* Least Significant Difference.

rees growing in shale and chert soils were higher in leaf nitrogen ontent, averaging 2.11 and 2.12 per cent respectively, the difference ver limestone being significant at the 5 per cent level. The potassium ontent of leaves was less in the shale and chert orchards than in rose orchards growing in limestone soil; the differences were stastically significant, The magnesium level of leaves in orchards grow$\mathrm{g}$ in limestone and shale was somewhat above that of trees grown in hert soils, possibly a chance result.

No great differences in nitrogen content of leaves were recorded Ir the different varieties considered (See Table 2). Stayman trees veraged lower in nitrogen than all others, and Delicious, Grimes olden, Golden Delicious, and York were definitely above the lowest tayman. York was distinctly lowest, and Stayman and Rome Beauty aves were intermediate in potassium content. This is in agreement ith results of Batjer and Magness (2), who in a national survey of the Jassium content of apple leaves, found that York and Jonathan aves were significantly lower than Delicious leaves, whereas the tassium content of Rome Beauty leaves was intermediate. Grimes, ed Delicious, and Rome as a group are significantly higher in rosphorus content than York, Stayman, and Golden Delicious as a oup. Calcium determinations showed that Delicious leaves were gnificantly lower in calcium than several other varieties, whereas olden Delicious leaves were significantly higher than Rome, Stayman, ad Delicious. Stayman leaves were the lowest in magnesium when impared to the other varieties in this survey. Although the average agnesium content of Stayman leaves was well above the critical vel, it will be shown later that several samples of Stayman leaves ere found below the critical level.

Many West Virginia apple orchards include blocks of trees that ve produced fruit for thirty years or more. Many old trees do not oduce as heaviiy as younger trees, and older orchards are generally re expensive to operate than young bearing orchards. In view of 
Table 2. Leaf analyses of apple orchards summarized according to variety.

\begin{tabular}{l|c|c|c|c|c|c|}
\hline & No. of & \multicolumn{5}{c}{ Mineral content expressed as per cent of dry weight } \\
\cline { 3 - 8 } Variety & orchards & nitrogen & phosphorus & potassium & calcium & magnesiur \\
\hline York Imperial & 54 & 2.02 & .179 & 1.35 & 1.33 & .283 \\
Delicious & 38 & 2.06 & .204 & 2.04 & 1.12 & .298 \\
$\begin{array}{l}\text { Stayman } \\
\text { Rome Beauty }\end{array}$ & 25 & 1.91 & .175 & 1.75 & 1.24 & .273 \\
$\begin{array}{l}\text { Grimes } \\
\text { Golden }\end{array}$ & 28 & 1.97 & .197 & 1.84 & 1.21 & .312 \\
$\begin{array}{l}\text { Golden } \\
\text { Delicious }\end{array}$ & 11 & 2.11 & .212 & 1.95 & 1.37 & .327 \\
LSD* & 2.04 & .175 & 1.97 & 1.41 & .324 \\
\hline
\end{tabular}

* Least Significant Difference

these facts, it is of interest to consider the mineral content of appl leaves as affected by the age of the trees. In Table 3 the average for trees less than thirty years of age are compared with trees ove thirty years of age. Analyses of Golden Delicious leaves are not in cluded in Table 3 because insufficient samples were available $\mathrm{fc}$ comparison.

Table 3. Leaf analyses of apple varieties in West Virginia accordin to tree age.

\begin{tabular}{|c|c|c|c|c|c|c|c|}
\hline \multirow{2}{*}{ Variety } & \multirow{2}{*}{$\begin{array}{c}\text { No. of } \\
\text { orchords }\end{array}$} & \multirow{2}{*}{$\begin{array}{l}\text { Age of } \\
\text { trees* } \\
\text { (years) }\end{array}$} & \multicolumn{5}{|c|}{ Mineral content expressed as percent of dry weigh } \\
\hline & & & nitrogen & phosphorus & potassium & calcium & magnesiu \\
\hline $\begin{array}{l}\text { York } \\
\text { Imperial }\end{array}$ & $\begin{array}{l}13 \\
41\end{array}$ & $\begin{array}{l}30- \\
31 t\end{array}$ & $\begin{array}{l}2.13 \\
1.99\end{array}$ & $\begin{array}{l}.190 \\
.176\end{array}$ & $\begin{array}{l}1.40 \\
1.32\end{array}$ & $\begin{array}{l}1.19 \\
1.37\end{array}$ & $\begin{array}{l}.312 \\
.276\end{array}$ \\
\hline Delicious & $\begin{array}{l}18 \\
20\end{array}$ & $\begin{array}{l}30- \\
31+\end{array}$ & $\begin{array}{l}2.15 \\
1.98\end{array}$ & $\begin{array}{l}.202 \\
.205\end{array}$ & $\begin{array}{l}2.09 \\
2.00\end{array}$ & $\begin{array}{l}1.11 \\
1.13\end{array}$ & $\begin{array}{l}.307 \\
.291\end{array}$ \\
\hline Stayman & $\begin{array}{l}18 \\
30\end{array}$ & $\begin{array}{l}30- \\
31+\end{array}$ & $\begin{array}{l}1.96 \\
1.88\end{array}$ & $\begin{array}{l}.168 \\
.179\end{array}$ & $\begin{array}{l}1.82 \\
1.71\end{array}$ & $\begin{array}{l}1.18 \\
1.28\end{array}$ & $\begin{array}{l}.284 \\
.266\end{array}$ \\
\hline $\begin{array}{l}\text { Rome } \\
\text { Beauty }\end{array}$ & $\begin{array}{l}13 \\
12\end{array}$ & $\begin{array}{l}30- \\
31+\end{array}$ & $\begin{array}{l}2.01 \\
1.92\end{array}$ & $\begin{array}{l}.203 \\
.191\end{array}$ & $\begin{array}{l}1.88 \\
1.80\end{array}$ & $\begin{array}{l}1.16 \\
1.27\end{array}$ & $\begin{array}{l}.309 \\
.314\end{array}$ \\
\hline $\begin{array}{l}\text { Grimes } \\
\text { Golden }\end{array}$ & 9 & $\begin{array}{l}30- \\
31+\end{array}$ & $\begin{array}{l}2.18 \\
2.08\end{array}$ & $\begin{array}{l}.191 \\
.222\end{array}$ & $\begin{array}{l}2.05 \\
1.90\end{array}$ & $\begin{array}{l}1.38 \\
1.37\end{array}$ & $\begin{array}{l}.365 \\
.310\end{array}$ \\
\hline
\end{tabular}

* Based on classification of trees into two groups: 30 years of age or und $(30-)$ and 31 years of age or more $(31+)$.

In each of the five varieties presented in Table 3, the older tree contained less nitrogen in the leaves than the younger trees. Althoul 
he differences are not great, the trend is consistent. This is lue largely to the frequent practice of increasing the nitrogen ipplication with increased age and size of trees up to about twentyive or thirty years, after which nitrogen fertilization is held to fairly :onstant amounts regardless of the size or bearing capacity of the rees. The potassium and magnesium levels in the leaves also were :enerally lower in the older trees than in the younger ones. Calcium, in the other hand, was higher in older trees with the single exception if the Grimes Golden samples. These showed no difference. No conistent trends were noted in the phosphorus content of apple leaves if young trees compared to older trees.

All averages shown in Tables 1, 2, and 3 are well above the generlly accepted critical levels for each mineral element. Six orchards, owever, contained trees that were low in potassium, and another six rchards included trees that were low in magnesium. The low poassium samples were taken from trees growing in all three soil lasses, and the low magnesium leaves all came from trees in the henandoah Valley growing in limestone soils. Detailed information $n$ these twelve samples is presented in Table 4.

The critical level of potassium in apple leaves, according to Batjer ad Magness (2), is about 1.0 per cent for York, and about 1.5 per cent it Delicious and Rome. Below these levels leaves are regarded as eficient in potassium and deficiency symptoms may appear. All amples in this survey below these levels are listed in the low poissium group in Table 4. Four samples of York leaves, one of Decious, and one of Rome showed less than the critical level of possium. In no case was any of the typical leaf scorch symptom of possium deficiency found on trees from which these samples were ken. The nitrogen levels of these low potassium leaves were relavely high, as can be seen in Table 4. Tree vigor was fair to good in 1 of the orchards from which these samples were taken, though the ees varied in age from thirty-five to fifty years.

Samples of four varieties, Stayman, York, Grimes, and Delicious, are found to be low in magnesium (See Table 4). All of these samples are taken from orchards in Berkeley and Jefferson counties; the age the trees varied from thirty to forty-five years. Only three of these mples were taken from trees exhibiting good vigor. All others came im trees showing fair to poor vigor. The nitrogen levels in these :es were all relatively low. Only one sample, No. 139, was as high 2.0 per cent in nitrogen. The magnesium content varied from 0.118 0.195 per cent. Considering 0.200 per cent as the critical level magnesium below which a deficiency exists, it can be seen from the 


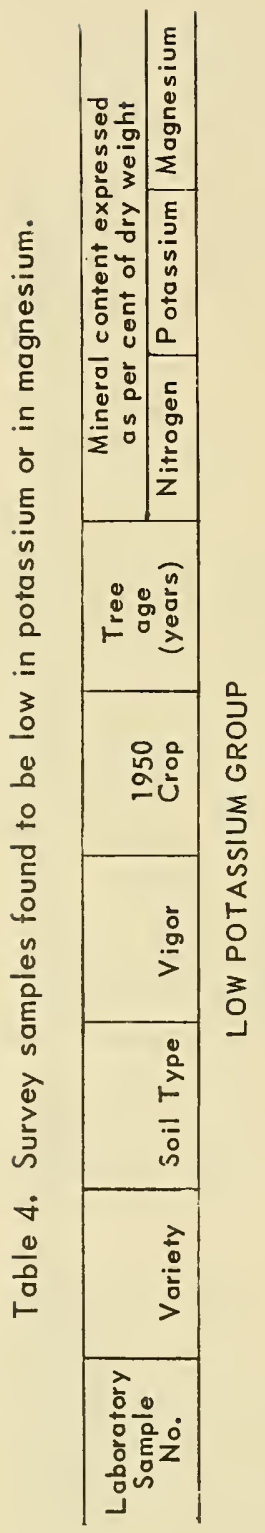

$\begin{array}{llllll}1 & 1 & 1 & 1 & 1 & 1 \\ 1 & 1 & 1 & 1 & 1 & 1\end{array}$

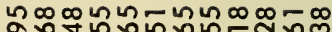

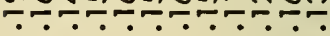

은요요

ดัด ำก

$\begin{array}{llllllllllll}1 & 1 & 1 & 1 & 1 & 1 & 1 & 1 & 1 & 1 & 1 & 1\end{array}$

$\begin{array}{llllllllllll}1 & 1 & 1 & 1 & 1 & 1 & 1 & 1 & 1 & 1 & 1 & 1\end{array}$

ำตํำ

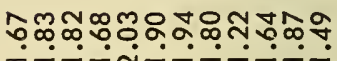

A

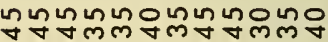

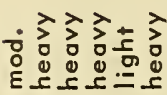

0
0
0
0
$\vdots$
$\frac{1}{5}$
$u$
$z$
$\vdots$
$z$
$z$
0

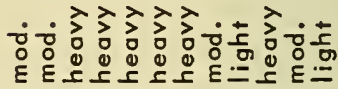

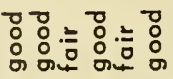

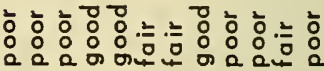

$\stackrel{0}{5} \stackrel{0}{\circ}$

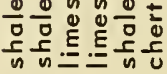

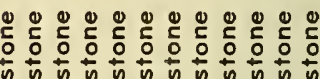

(1)

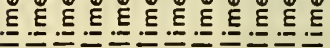

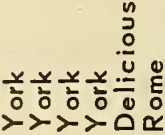

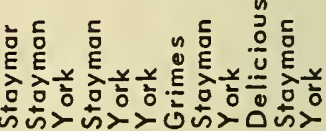

Mে

ำตำ๊ำํำกNำ 
igures in Table 4 that some of the samples were critically low in magbsium. However, no clear cut deficiency symptoms appeared on the oliage of the trees from which these samples were taken.

\section{SIGNIFICANCE OF THE SURVEY}

This survey, although not all inclusive, - was reasonably repreentative of the orchards of West Virginia. It included six major varicles, the three major soil classes upon which orchards are grown, and cross section of orchards varying from vigorous, well-managed, highroducing blocks to marginal ones in the major apple region of the tate. The analyses made indicate that generally the orchards of West irginia are receiving adequate nutrition. Most of the trees sampled sowed levels of nitrogen, phosphorus, calcium, potassium, and mag:sium well above the critical levels of these elements. $\Lambda$ few indidual orchards in addition to those in the low magnesium group f Table 4) had varying degrees of nitrogen deficiency. No phosphorus ficiency was found, and only six low magnesium and six low possium samples were found in the 209 samples collected. It is aprent, therefore, that the general recommendation of nitrogen only for e apple orchards of West Virginia remains sound.

It is evident, however, that instances of low potassium and low "gnesium levels in apple trees do exist in the State. This should it be interpreted as a signal for widespread use of these elements in I: orchard fertilization program. The frequency of these deficiencies ithe survey reported here was small, and the orchards were scattered loughout the Eastern Panhandle, rather than being concentrated in 8/ particular region ox on any particular soil type. Furthermore, the istence of an actual deficiency is only suggested by this survey. It bains to be determined whether or not the orchards in question will pond to applications of potassium or of magnesium.

Recent research has demonstrated that no single element can be isidered by itself, but must be regarded in terms of its position with :rence to the levels of other elements present. For example, it is wn that the addition of large quantities of nitrogen fertilizers to le trees will depress the potassium level in the leaves $(6,8)$. It is nterest to note that in all the orchards that showed low potassium, nitrogen in the leaves was at an average or higher than average 1. Furthermore, no visual symptoms of potassium deficiency could iound in any of these orchards.

Similarly, the low magnesium levels (reported in Table 4) may or not be indications of a simple magnesium deficiency. The levels 
of other elements are known to have a marked influence on the level of magnesium in apple leaf tissue. Conclusive evidence has recently been obtained to show that under certain conditions applications of potassium fertilizers can induce a magnesium deficiency in the apple orchard (7), and that the appearance of a magnesium deficiency is usually closely associated with a high potassium level in the trees Also, it has been found that the magnesium level of apple leaves in creases when the nitrogen level is increased $(3,8)$.

In this survey, every low magnesium sample came from trees tha had an optimum-though not high-level of potassium, but generally low level of nitrogen. In the orchard where the lowest magnesium leve was found (sample No. 172, Table 4), analyses showed that the leave: contained only 0.118 per cent magnesium and only 1.22 per cent nitro gen. In the fall of 1950 the operator applied nitrogen in this orchar for the first time in several years. This application, which consiste of five pounds of nitrate of soda per tree, was followed by two spra applications of urea each at five pounds per 100 gallons in the sprin of 1951. Another sampling was made in this orchard on August 1( 1951. Analyses of these samples (Table 5) showed an increase in th nitrogen level of the leaves from 1.22 per cent to 1.93 per cent a ye later. It is of interest to note that the magnesium level also was co siderably higher in 1951. These trees in 1951 contained $0.210 \mathrm{P}$ cent magnesium in the leaves, or approximately the amount regard as the critical level below which deficiency symptoms are likely appear. This illustrates that the low magnesium levels found in th survey may indicate actual magnesium deficiencies, or they may some cases be simply a reflection of insufficient nitrogen fertilizati in the orchard.

The information obtained in these analyses will be used planning further nutrition work to determine the nature of the deficis cies found, and the most economical means of dealing with them.

Table 5. Effect of nitrogen applications on the levels of nitrogen cd magnesium in apple leaf tissue (York variety).

\begin{tabular}{c|c|c|c}
\hline \multirow{2}{*}{ Somple number } & \multirow{2}{*}{ Year* } & \multicolumn{2}{c}{$\begin{array}{c}\text { Minerol content of leaves expres } \\
\text { as per cent of dry weight }\end{array}$} \\
\cline { 2 - 4 } & 1950 & Nitrogen & Magnesiui \\
\hline \multirow{2}{*}{ - } & 1951 & 1.22 & .118 \\
& 192 & 1.93 & .210 \\
\hline
\end{tabular}

*These trees were fertilized with 5 pounds per tree of nitrate of soda in fall of 1950; two sprays of urea each at 5 pounds per 100 gollons were app in the spring of 1951 . 


\section{LITERATURE CITED}

Alderman, W. H. and Crane, H. L., The Fertilization of Apple Orcbards. W. Va. Agr. Exp. Sta. Bull. 174: 1-51, 1920.

Batjer, L. P. and Magness, J. R., "Potassium Content of Leaves from Commercial Apple Orchards." Proc. Amer. Soc. Hort. Sci. 36: 197-201 (1938).

Beattie, James M., and Ellenwood, C. W., "A Survey of the Nutrition Status of Ohio Apple Trees." Proc. Amer. Soc. Hort. Sci. 55: 47-50 (1950).

Boynton, Damon, Reuther, Walter, and Cain, J. C., "Leaf Analysis and Apparent Response to Potassium in Some Prune and Apple Orchards." Proc. Amer. Soc. Hort. Sci. 38: 17-20 (1941).

Cain, J. C., and Van Geluwe, J., "Incipient Ma gne sium Deficiency in Some New York Apple Orchards." Proc. Amer. Soc. Hort. Sci. 42: $95-100$ (1943).

and Compton, O. C., "The Influence of Differential Fertilization with Ammonium Sulfate on the Chemical Composition of McIntosh Apple Leaves." Proc. Amer. Soc. Hort. Sci. 45: 9-17 (1944).

, and Burrell, A. B., "Potassium-induced Magnesium Deficiency in the McIntosh Apple Tree." Soil Sci. 58: 441-454 (1944).

Cain, J. C. and Boynton, Damon., "Some Effects of Season, Fruit Crop, and Nitrogen Fertilization on the Mineral Composition of McIntosh Apple Leaves." Proc. Amer. Soc. Hort. Sci. 51: 13-22 (1948).

Chucka, J. A., Waring, J. H., and Wyman, O. L., "Magnesium Deficiency in Maine Apple Orchards." Proc. Amer. Soc. Hort. Sci. 46: 13-14 (1945).

Lindner, R. C., "Rapid Analytical Methods for Some of the More Common Inorganic Constituents of Plant Tissues." Plant Pbysiol. 19 (1): $76-89$ (1944).

Schrader, A. Lee., Scott, L. E., and Dunbar, C. O., "The Nutritional Status of Maryland Orchards in Terms of Mineral Content of Leaves and Occurrence of Deficiency Symptoms." Proc. Md. State Hort. Soc. 3-10 (1949).

Southwick, Lawrence, "Magnesium Deficiency in Massachusetts Apple Orchards." Proc. Amer. Soc. Hort. Sci. 42: 85-94 (1943). 
